during the present century fall within the group of minimum sun-spot years, the sixth (1854) being also a year of relatively few sun-spots (19.2 according to Wolf).

Dr. Hunter's avowed object, however, in writing his pamphlet was to prove that a cycle of drought sufficient to cause famine existed throughout the whole of Southern India, and with this end in view he has been content to show that a cycle of rainfall corresponding with the period of solar maculation existed merely for one single station, viz., Madras.

Having found a decided correspondence between the rainfall of Madras and the eleven-year period of sun-spots, he thence argues somewhat hastily that the same conditions apply throughout the whole of Southern India. This hasty generalisation from the results of one station situated in a vast continent, the rainfall of which varies completely both in amount and the season in which it falls, according to locality, has been strongly contested by Mr. Blanford, the Government meteorologist, who on making a careful comparison of the rainfalls of seven stations, three of which-Madras, Bangalore, and Mysore-are in Southern India, the others being Bombay, Nagpore, Jubbulpore, and Calcutta, finds that with the exception of Nagpore in Central India, which shows some slight approach to the same cyclical variation which is so distinctly marked in the Madras registers, the rest of the stations form complete exceptions to the rule adduced for Madras, in many of them the hypothetical order of relation being reversed. Mr. Blanford, however, shows that underlying the above irregularities a certain cyclical variation exists on the average at all the stations, the amount nevertheless being so insignificant (not more than 9 per cent. of the toral falls) that it could not possibly be considered of sufficient magnitude to become a direct factor in the production of famine. It thus appears that the cycle of rainlall which is considered to be the most important element in causing periodic famines, has only been proved satisfactorily for the town of Madras. It may perhaps hold for the Carnatic and Northern Siccars--the country immediately surrounding Madras, though, owing perhaps to the want of rainfall registers in these districts, evidence with regard to this point is still wanting.

Though Dr. Hunter has thus been only partially successful, I would not attempt to detract in any way from the value of his able pamphlet, so far as it goes, an indirect effect of which has been to stimulate meteorological inquiry and research in the same direction throughout India. The meteorology of this country, from its peculiar and tropical position, is in such complete unison with any changes that may arise from oscillations in the amount of solar radiation and their effects upon the velocity and direction of the vapour-bearing winds, that a careful study of it cannot fail to discover meteorological periodicities in close connection with corresponding periods of solar disturbance. In connection with the previous remarks, and as showing what a close connection exists between solar and terrestrial meteoroloyy, I may observe that $\mathrm{Mr}$. Hill, the meteorologist for the NorthWest Provinces, and myself, have coincidently discovered the existence of a remarkable cycle in the winter rainfall of Northern India, between the latitudes of $20^{\circ}$ and $30^{\circ}$, corresponding in. versely with the period of solar spots, i.e, the maximum winter rainfall coincides with the minimum period of sun-spots, and vice versâ.

As a failure of the winter rains in the Northern Provinces in $x$ 860-6I ( $y$ tars of maximum sun-spot) has been the cause of a severe famine, this theory, if completely established, would not be without its value in the economical administration of the North-West Provinces and the Punjab. I have not at present examined the rainfalls of all the stations in the Upper Provinces, but Mr. Hill, having readier access to them than myself, has probably done so to a larger extent, and tells me that the results of his investigations are similar to my own in bearing out the preceding hypothesis. A theory is not wanting to account for this tendency to vary inversely with the sun-spots, if we, according to opinion held by Drs. Hahn and Köppen, Prof. Piazzi Smyth, and Mr. Pogson, the Government astronomer at Madras, assume that the sun's heat is greater in years of minimum sun-spot. For in these years the anti-trade current, the descent of which upon the Himalaya and Northern India in the winter is generally understood to be the vehicle of the rain at that season, would be owing to the increased evaporation over the Southern Indian Ocean, reinforced with a Jarger supply of vapour than usual, while in years of maximum sun-spot the supply would be smaller. At all events, whatever be the real cause, the facts as far as we have gone, are exceedingly favourable to the existence of such a cycle. Calcutta, though lying close to the tropics, and therefore coming in for a small share of winter rainfall, still shows the preceding relation to a wonderful extent, and as its register of rainfall extends farther back than most of the other North Indian rainfalls, furnishes a more trustworthy result than many other stations whose rainfalls registered only for short periods scarcely afford more than a slight balance of probability in favour of the assumption. The following table is arranged in a double series of years occupying the same position in the spot-cycle, and gives the average rainfall for each double series for the months of November, December, January, February, March, and April, from 1837 to 1876 inclusive. I have indicated the groups containing the years of maximum and minimum sun.spot. The maximum rainfall will be seen to occur in the latter, and the n: inimum in the former group.

Calcutta Rainfall during the months of November, December, Fanuary, February, March, and April.

$$
\text { Years. }
$$

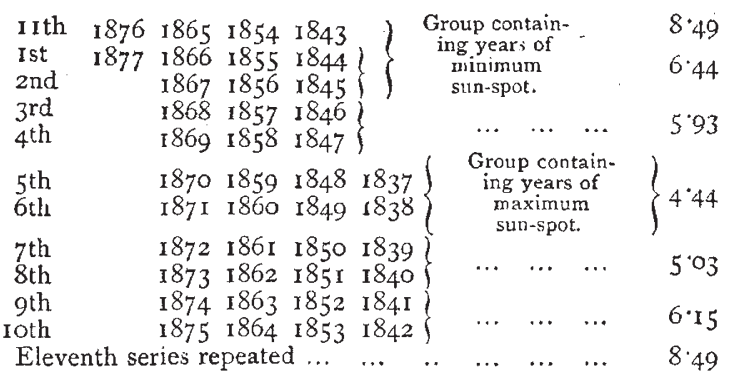

Further analysis only tends to render the connection still more evident, but I have no time to add anything further. In conclusion I need only remark that Jerusalem, which is situated somewhere about the same latitude as Lahore, and receives its total annual supply during the winter months alone, fully bears out the hypothesis as far as records show from 1846 to 1859 .

Bankipore, Patna

E. D. ARCHIBALD

\section{Reproduction by Conjugation}

IN Prof. Allen Thomson's Inaugural Address to the British Association, I find the following sentence, referring to the simplest form of sexual reproduction amung cryptogams, known as conjugation:- "In more ordinary cases, as in Spirogyra, where the embryo is formed in one of the two cells, it seems to be indifferent in which of them it is formed." If my own experience may be taken as trustworthy and adequate, there is one fact in connection with this phenomenon which would seem to show that it may not be altogether indifferent, and that the differentiation of male and female elements may be carried back even one step further than is stated by this distinguished biologist. When two filaments-which we may call $\mathrm{A}$ and $\mathrm{B}$-are conjugating, then, as far as my observation has gone, the direction of conjugation is uniformly the same, i.e., either the contents of every cell in $A$ pass over into the adjacent cell of $B$, or the reverse ; we never find the contents of some of the cells of $A$ passing over into $B$, and the contents of some of the cells of $B$ passing over into $A$. If this is so, and if we call the filament in which the zygospores are ultimately produced $\mathrm{A}$, then it is clear that we may fairly call $A$ the female and $B$ the male fila. ment; and it would appear certain that there must be some hitherto undetected difference between them. My own observations in this respect relate almost exclusively to Spirogyra, and I shall be very glad to know if they are confirmed, or otherwise, by those of more experienced algologists.

\section{ALFRED W. BENNETI}

\section{The Greenland Foehn}

HOFFMEYER'S facts respecting spells of warm weather in the Arctic winter, as reported in NATURE, vol. xvi. p. 294, are very interesting, but his explanation of them seems demonstrably insufficient. He thinks they are a phenomenon of the same kind with the Foehn of the Alps, which latter he explains by saying that a wind which at its origin is saturated with moisture $x$ ill, when it is forced over a mountain chain, be raised $x^{\circ}$ Cent. for 